Помиткіна Любов Віталіївна доктор психологічних наук, професор, завідувач кафедри авіаційної психології Національного авіаційного університету, пр. Любомира Гузара, 1, м. Київ, 03058, тел.: (099) 138-4738, e-mail: Lyubvit@ukr.net, https://orcid.org/0000-0002-2148-9728

\title{
ОСОБЛИВОСТІ ПСИХОЛОГІЧНОЇ ПІДГОТОВКИ ПАТРУЛЬНОЇ ПОЛІЦІї ДО ДІЯЛЬНОСТІ В СКЛАДНИХ СИТУАЦІЯХ КОРОНОВІРУСНОЇ ПАНДЕМЇ̈
}

Анотація. У статті подані результати теоретичного аналізу особливостей психологічної підготовки операторів до діяльності в складних ситуаціях короно вірусної пандемії та результати емпіричного дослідження працівників патрульної поліції, яка курсує на оперативних автомобілях і здійснює контроль за пересуванням осіб, які прибули із-за кордону, зробили тест на ПЦР і до отримання його результатів мають перебувати на самоізоляції.

Метою статті є висвітлення особливостей розвитку психологічної готовності особистості до діяльності в особливих умовах та результатів емпіричного дослідження рівня прояву психогенних характеристик патрульної поліції під час виконання оперативних завдань.

Для емпіричного дослідження були використані психодіагностичні методики: «Самооцінка психічних станів» Г. Айзенка, «Визначення стресостійкості особистості», «Індикатор копінг-стратегій» Д. Амірхана та «Накопичення емоційно-енергетичних зарядів, спрямованих на самого себе» В.В. Бойко.

У результаті були отримані: середні й високі показники стресостійкості, достатня здатність до подолання тривожності й опору фрустрації; найбільше поліцейські використовують копінг-стратегію - вирішення проблем, що свідчить про високий рівень знань та навичок, хорошу комунікацію 3 оточуючими, великий запас внутрішніх ресурсів, самоконтроль та адекватну самооцінку себе й своїх професійних дій. Однак, присутність постійного ризику впливає на емоційний стан, а це в свою чергу породжує стан напруженості, тому було зафіксовано наявність середнього рівня емоційної прихованої напруги, що свідчить про емоційне виснаження, що в подальшому може спричини емоційне та професійне вигорання.

Отримані дані засвідчили необхідність психологічної підготовки працівників патрульної поліції під час короновірусної пандемії. 
Ключові слова: особистість, оперативні ситуації, пандемія, патрульна поліція, психологічна готовність, стресостійкість.

Pomytkina Liubov Vitaliivna Doctor of Science, Professor, Head of the Department of Aviation Psychology at the National Aviation University, Liubomyra Huzara Ave., 1, Kyiv, 03058, tel.: (099) 138-47-38, e-mail: Lyubvit@ukr.net, https://orcid.org/0000-0002-2148-9728

\title{
PECULIARITIES OF PSYCHOLOGICAL TRAINING OF PATROL POLICE FOR ACTIVITY IN DIFFICULT SITUATIONS OF CORONOVIRUS PANDEMIC
}

\begin{abstract}
The article presents the results of theoretical analysis of peculiarities of operators' psychological training for activity in difficult situations of coronavirus pandemic and the results of empirical research of patrol police officers who work on operational vehicles and monitor the movement of persons who came from abroad, tested by PCR and prior to obtaining its results must be in self-isolation.

The purpose of the article is to highlight the peculiarities of development of the personality's psychological readiness for activity in special conditions and the results of an empirical study of the manifestation level of psychogenic characteristics of the patrol police during operational tasks.

Psychodiagnostic methods were used for empirical research: "Self-assessment of mental states" by G. Eisenko, "Determination of personality stress resistance", "Indicator of coping strategies" by D. Amirkhan and "Accumulation of emotional and energy charges directed at oneself" by V.V. Boyko.
\end{abstract}

As a result we have obtained: medium and high stress resistance indicators, sufficient ability to overcome anxiety and resistance to frustration; the policemen mostly use coping strategy - solving problems, which indicates a high level of knowledge and skills, good communication with others, a large stock of internal resources, self-control and adequate self-assessment of themselves and their professional actions. However, the presence of constant risk affects the emotional state, which in turn creates a state of tension, therefore the presence of an average level of emotional latent tension was recorded, indicating emotional exhaustion, which can further cause emotional and professional burnout.

The data obtained showed the need for psychological training of patrol police officers during the coronavirus pandemic.

Keywords: personality, operational situations, pandemic, patrol police, psychological readiness, stress resistance. 
Постановка проблеми. Масштабність поширення короновірусної пандемії вимагає підвищення вимог щодо підготовки працівників оперативного складу $\mathrm{MBC}$, які відповідальні за здоров`я громадян та, в цілому, за порядок в нашій країні. На сьогодні, крім вимог до наявності високого рівня розвитку основних професійно важливих якостей до роботи в особливих умовах, спостерігається посилена увага до певного рівня психологічної готовності щодо здійснення професійної діяльності в складних ситуаціях що склалася.

Вчені й практики (Алещенко В. І., Бабаян Ю. О., Осьодло В. І., Сафін О. Д., Смирнов Б. А., Потапчук С. М. та ін.) відмічають, що крім професійних знань, умінь і навичок, працівникам оперативного складу в надзвичайних ситуаціях потрібно бути психологічно готовими до виконання своїх обов’язків. У науковій літературі визначається, що психологічна підготовка - це досить тривалий процес цілеспрямованого формування психічних якостей, які забезпечують готовність працівників до успішних дій в різних умовах функціонування, аж до найекстремальніших [2, 4]. Тут необхідно зазначити, що психологічну готовність трактують як одну 3 необхідних складових у загальній готовності працівників до діяльності в особливих та екстремальних умовах.

Аналіз останніх досліджень і публікацій. На сьогодні психологічну підготовку до роботи в екстремальних ситуаціях досліджують як в соціогуманітарних напрямах (Ічанська О.М., Помиткіна Л.В., Хохліна О.П., Яковицька Л.С. та ін.) так і в технічних (Корольчук М.С., Фугелова Т.А., Shevchuk D., Yakushenko O. а ін.), і визначають, що - це система заходів щодо формування у працівників стану психологічної готовності до подолання негативного впливу стрес-чинників надзвичайної ситуації й ефективного вирішення професійних завдань [3; 7; 9].

В основі досягнення у кожного фахівця, зокрема i оператора, стану психологічної готовності лежить процес формування стійких психічних якостей, необхідних для виконання будь-якого поставленого завдання в різних умовах професійної діяльності, а також здатності протистояти психотравмуючим чинникам. Це є головною метою психологічної підготовки [5; 7]. Як вказують вчені й практики, найбільша результативність психологічної підготовки досягається при зміні заданих ситуацій як у ході навчального тренування, так і в ході професійної діяльності [10; 11$]$.

Метою статті є висвітлення особливостей психологічної підготовки особистості до діяльності в особливих умовах та результатів емпіричного дослідження рівня прояву психогенних характеристик патрульної поліції під час виконання оперативних завдань.

Виклад основного матеріалу. На сьогодні, вчені виділяють різні рівні психологічної готовності [5; 9]: 
1. Загальна (тривала) психологічна готовність (ЗПГ) - потенційна здатність фахівця здійснити переналаштування психіки адекватно виду професійного завдання, що вирішується. Основу ЗПГ складає система моральнопсихологічних якостей, що визначають потенційну здатність працівників до подолання труднощів професійної діяльності.

2. Ситуативна психологічна готовність (СПГ) - психічний стан, що сприяє подоланню конкретних труднощів професійної діяльності, у якому провідну роль відіграють такі компоненти:

мотиваційний - різні мотиваційні тенденції, що виконують спонукальну, мисленєво-утворюючу та регулятивну функцію;

емоційно-вольовий, що виконує контрольно-оцінну функцію;

пізнавальний, що забезпечує функцію створення, структурування орієнтовної основи професійної дії, поточного аналізу та прогнозування динаміки професійних ситуацій;

операційний, що передбачає володіння способами та прийомами, необхідними навичками й уміннями з використання спеціальної техніки та обладнання, високу фізичну підготовленість;

комунікативній, який характеризує соціально-психологічний аспект діяльності фахівців, стан готовності до взаємодії з товаришами по службі та постраждалим населенням.

Операційно-виконавча психологічна готовність формується на основі загальної та ситуативної психологічної підготовленості та включає поведінкові реакції людини, способи дії, які набули рефлекторного характеру і не вимагають включення свідомості для побудови програми діяльності.

Сукупність структурних компонентів стану психологічної готовності та їх взаємодія зумовлені специфікою об'єктивних умов діяльності при виконанні професійного завдання і пов'язані 3 певним ступенем перешкодостійкості до зовнішніх і внутрішніх впливів під час прийняття рішень [10; 12$]$.

Найважливішими завданнями психологічної підготовки на етапі підготовки до виконання службових обов'язків в особливих умовах є [9;14]:

формування професійної спрямованості особистості фахівця;

мотивування фахівця до активних і самовідданих дій у різноманітних ризико-небезпечних ситуаціях професійної діяльності;

ознайомлення 3 характерними труднощами професійної діяльності при проведенні діяльності в особливих та екстремальних умовах та специфікою iі впливу на психіку;

забезпечення стійкості навичок володіння спеціальною технікою та обладнанням і способів професійної поведінки;

- фізична підготовка, формування силової та швидкісної витривалості, 
здатності переносити тривалі фізичні навантаження;

формування навичок взаємодії та комунікації в умовах групової діяльності; навчання прийомів управління своїм психічним станом і способів впливу на стан у скрутних професійних ситуаціях, способів мобілізації додаткових психологічних можливостей для подолання цих труднощів;

формування навичок i вмінь психологічної саморегуляції, вольової мобілізації, зниження больових відчуттів, визначення та активізацій психічних і фізичних можливостей для вирішення професійних завдань.

На етапі реального виконання службових обов'язків формується ситуативна психологічна готовність, а на іï основі - операційно-виконавча психологічна готовність. Завданнями цього етапу $\epsilon$ розвиток і зміцнення мотиваційного, емоційно-вольового, пізнавального, комунікативного та операційного (моторного) компонентів психологічної готовності операторів [5, с. 207-218]:

1) Мотиваційний компонент включає надання особистісного значення виконанню завдань професійної діяльності, зміцнення прагнення успіху, високої відповідальності, розвиток прагнення у всьому слідувати традиціям професії, прагнення до найкращого виконання завдання [11].

2) Емоційно-вольовий компонент складає психологічна адаптація до чинників службово-професійної обстановки, розвиток почуття упевненості в собі, у товаришах, в успішному виконанні поставлених завдань, розвиток саморегуляції, самоконтролю, самомобілізації, здатності долати страх i протистояти паніці, підтримка оптимального збудження; формування стійкості до несприятливих впливів; уміння мобілізувати можливості на подолання труднощів, що виникли.

3) У пізнавальний компонент включається: формування уявлень про майбутні професійні дії, можливі зміни в обстановці; розвиток довготривалої та оперативної пам'яті, їх стійкість у період емоційного навантаження; розвиток навичок швидко оцінювати обстановку; формування потреби в нових професійних знаннях.

4) В основі комунікативного компонента лежать: розвиток здатності ефективно взаємодіяти; прагнення до взаємодопомоги; формування правильного стилю спілкування; здібності до встановлення контактів з оточуючими.

5) У структурі операщзійного (моторного) компонента виділяються: вдосконалення фізичної підготовленості, здатності тривалий час переносити високі навантаження; розвиток швидкості, чіткості, точності й безпомилковості рухів в умовах емоційного навантаження, попередження типових промахів i помилок у діях і поведінці операторів, вироблення високої працездатності.

Перераховані завдання вирішуються не тільки в інтересах психологічної підготовки, але й для профілактики психічних втрат, психологічної реабілітації 
працівників тощо.

Психологічна підготовка поділяється на загальну, спеціальну й цільову [4; 6]:

- Загальна підготовка призначається для формування у фахівців системи психологічних якостей необхідних для діяльності в особливих та екстремальних умовах. Її специфічний зміст полягає у формуванні у працівника міцних уявлень про професійні завдання, труднощі професійної діяльності, тощо.

- Спеціальна підготовка здійснюється 3 метою досягнення стійкої психологічної готовності для виконання завдань у різних видах професійної діяльності.

- Цільова підготовка передбачає формування психологічної готовності долати труднощі конкретних складних чи екстремальних ситуацій.

Зрозуміло, що формування психологічної готовності і стійкості співробітників національної поліції забезпечується при певній психологічній підготовці. Цей процес можна розбити на три визначні етапи [6]:

1. Етап завчасного формування готовності до дій в складних та екстремальних ситуаціях.

2. Етап безпосереднього формування готовності до виконання складного завдання.

3. Етап підтримання готовності до складних ситуацій у процесі виконання складного завдання.

Отже, основним змістом своєчасного формування готовності до дій в складних та екстремальних ситуаціях $є$ формування і виховання у співробітників національної поліції [8]:

- впевненості у собі, власній підготовленості, у колегах по виконанню завдань, у можливості успішного переборювання труднощів в оперативнослужбовій діяльності, готовності до зустрічі з ними;

- глибоких та переконливих знань про можливі варіанти напружених ситуацій, їх сутність, особливості і способи їх розрядки;

- гарантовано розвинутих вольових якостей, таких як цілеспрямованість, активність, енергійність, самостійність, обачливість, сміливість, витривалість, самовладання;

розвинутих якостей - психологічної надійності, стійкості до небезпеки та ризику, до великого перенапруження, до тимчасових невдач та очікуваних труднощів;

досвіду і навичок швидкого і якісного переходу від очікування до вкрай напружених дій.

Як вказують вчені й практики, основною метою психологічної підготовки є практична підготовка співробітників до успішного подолання психологічних труднощів службової діяльності і правильного врахування іiі психологічних 
аспектів. При психологічній підготовці обранці здобувають [8;10]:

- формуються потрібні професіоналу вміння виявляти психологічні чинники, аналізувати їх на практичному рівні і правильно оцінювати екстремальні ситуації;

- розвивається інтерес співробітника до психолого-педагогічних аспектів діяльності, прагнення до пошуку обгрунтованих відповідей на складні запитання, здатність глибше вивчати і краще розуміти мотиви вчинків людей і будувати з ними свої взаємостосунки, виходячи з особливостей, психологічних станів і інтересів справи;

- виробляється - психологічна рефлексія (схильність до психологічного самоаналізу, самооцінки).

У науковій літературі визначається, що основними завданнями психологічної підготовки є [6;8]:

1. Озброєння співробітників національної поліції психологічними знаннями, необхідними для комплексної оцінки й урахування психологічних аспектів службової діяльності, а також знаннями про різні варіанти екстремальних ситуацій, їх сутність, особливості способи їх подолання.

2. Розвиток професійно-психологічних якостей - професійної, спостережливості, професійної пам'яті тощо.

3. Формування навичок виконання професійних дій у будь-яких варіантах екстремальних умов i керування собою, умінь користуватися психологічними прийомами ( мовленням, мімікою, жестами ) для підвищення ефективності встановлення контакту при професійному спілкуванні.

4. Формування психологічної стійкості до труднощів, які виникають при розв’язанні службових задач в екстремальних, психологічно складних ситуаціях, $\mathrm{i}$ способів дій у них.

Психологічна підготовка повинна займати самостійне місце в системі професійної підготовки. У той же час це не виключає можливості використання окремих психологічних елементів i прийомів при проведенні занять зі спеціальної, бойової і фізичної підготовки в окремих підрозділах національної поліції, що може здійснюватися у вигляді:

- збільшення темпу діяльності, скорочення термінів виконання задачі;

- розв’язання задачі при нестачі інформації, активній протидії з наявністю елементів ризику і небезпеки;

введення в заняття несподіваних перешкод і ускладнень;

постановки задач, які вимагають самостійного вибору з кількох можливих варіантів їх розв'язання;

- створення ситуацій, які ведуть до невдачі і вимагають надалі підвищеної активності; 
внесення змагального елементу;

постановки задач, які вимагають взаємодії і взаєморозуміння.

Підсумком психологічної підготовки $\epsilon$ формування стану професійнопсихологічної готовності співробітника національної поліції як сукупності психофізіологічних, морально-психологічних, професійних і соціальнопсихологічних характеристик, властивостей i якостей, які відповідають особливостям оперативно-службової діяльності і виступають внутрішньою умовою їі успішного здійснення.

Емпіричне дослідження. Респондентами емпіричного дослідження виступили працівники Національної поліції України, зокрема, патрульна поліція, яка курсує на оперативних автомобілях і здійснює контроль за пересуванням осіб, які прибули із-за кордону, зробили тест на ПЦР і до отримання його результатів мають перебувати на самоізоляції. Однак, нажаль, не усі громадяни мають високу свідому позицію у цьому питанні, тому патрульній поліції необхідно вживати певних заходів, які часто можуть супроводжуватися стресовими ситуаціями.

Методи дослідження. Для визначення рівня психологічної готовності до діяльності в особливих і стресогенних умовах респондентів були обрані наступні психологічні методики дослідження: «Самооцінка психічних станів» Г.Айзенка, «Визначення стресостійкості особистості», «Індикатор копінг-стратегій» Д. Амірхана та «Накопичення емоційно-енергетичних зарядів, спрямованих на самого себе» В.В. Бойко. Проведення опитування за даними методиками надасть можливість з`ясувати рівень прояву у респондентів вищезазначених професійних якостей та засвідчить необхідність або достатність психологічної підготовки у них.

Результати. За результатами опитування були отримані наступні дані, які узагальнені нами та представлені на рис.1-4.

За даним графіком (рис. 1) видно, що у представників патрульної поліції показники психічних станів домінують основному на низькому рівні. Такі результати свідчать про наступне: у поліцейських присутня тривожність у діяльності через складні умови роботи, які часто можуть ставити під загрозу їхнє життя. Фрустрація у респондентів перебуває на домінуючому низькому рівні, що говорить про здатність поліцейських у будь яких умовах виконувати складні завдання та задовольняти потреби; варто зазначити, що показник агресивності у респондентів переважає на низькому рівні, що говорить про наявність самоконтролю, розуміння у ставленні до інших та відсутність самоагресії. Також у респондентів спостерігається низький рівень ригідності, що свідчить про здатність патрульних перебудовувати свою діяльність, швидко іiі змінювати, адаптуватись та реагувати на змінні обставини. 


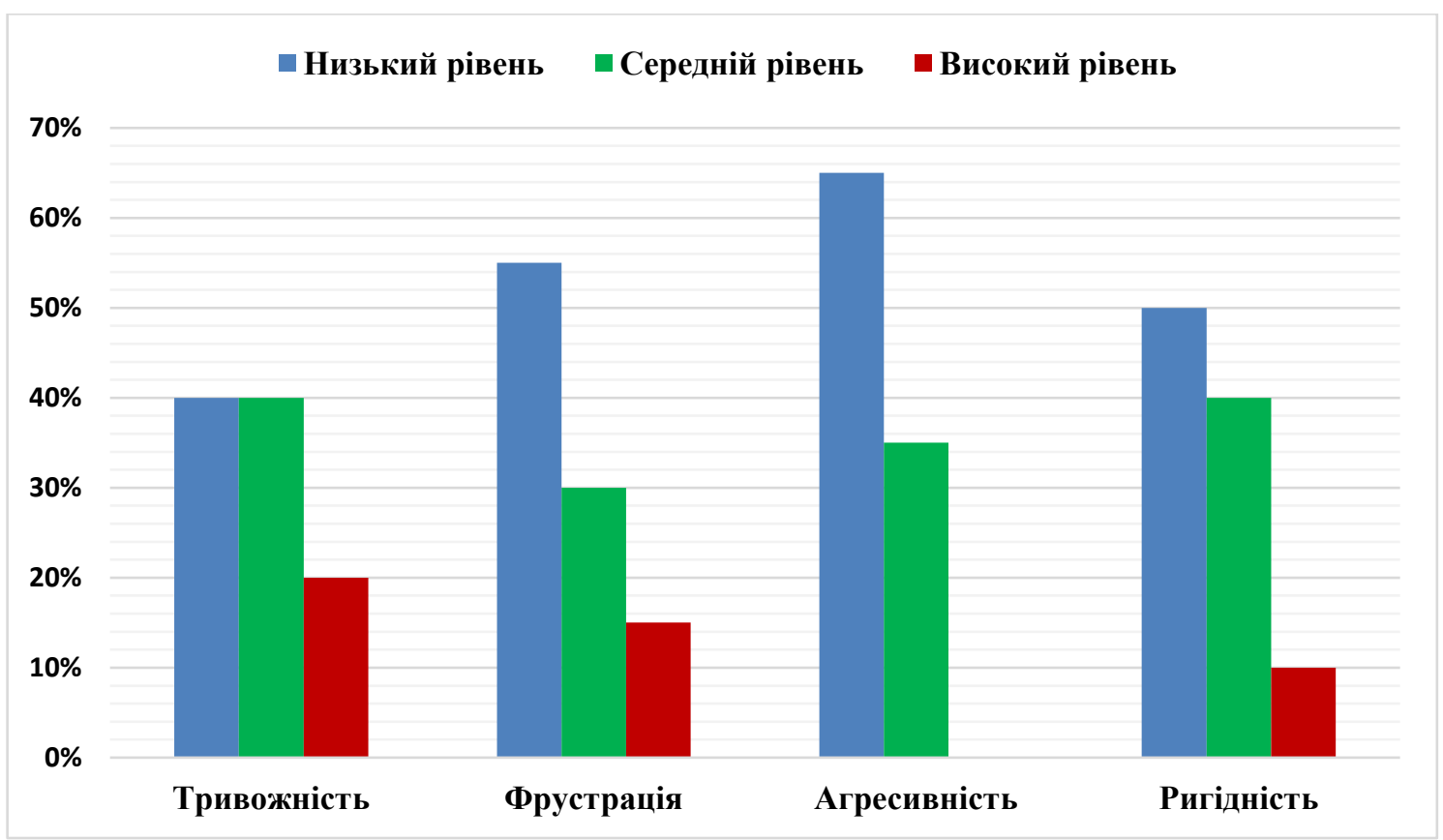

Рис.1. Розподіл рівня прояву психічних станів у респондентів

За даними із рис. 2 видно, що стресостійкість у респондентів проявилась на таких рівнях: по 10\% - низький та нижче середнього рівні, у 40\% - середній рівень, у 5\% респондентів - рівень вище середнього, а високий рівень зафіксований у $35 \%$. Отже, домінуючими рівнями стресостійкості у поліцейських є середній (40\%) та високий (35\%).

- Дуже низький

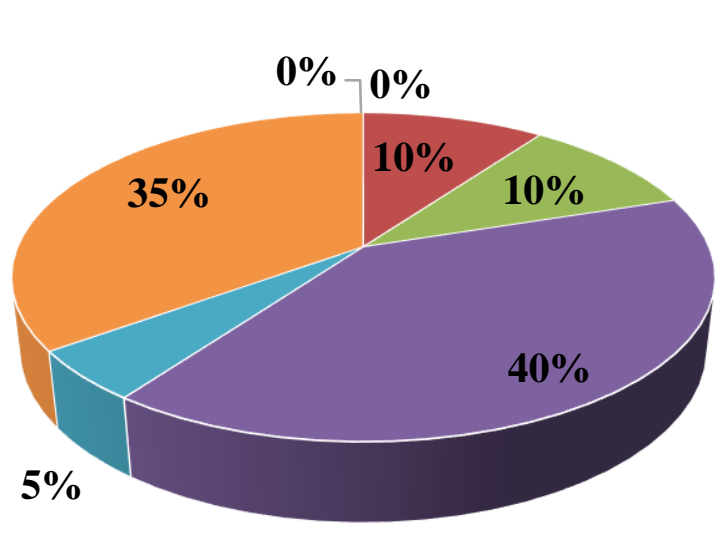

- Дуже високий

- Низький

- Нижче середнього

- Середній

- Вище середнього

- Високий

Pис. 2. Розподіл стресостійкості у респондентів

За такими показниками можна говорити про здатність поліцейських протистояти стресам та долати стресові ситуації, також це свідчить про високий рівень внутрішніх ресурсів, стійкість нервової системи та емоційну стійкість.

Щодо вибору копінг-стратегій патрульними поліцейськими отримані наступні дані, що подані на рис. 3: у респондентів домінують такі показники 
використання копінг-стратегій як «стратегія вирішення проблем» переважає у 50\% на високому рівні, «стратегія пошуку соціальної підтримки» - переважає у 35\% на середньому рівні, а «стратегія уникання проблем» домінує у 40\% респондентів на середньому рівні. Дані показують, що найбільше поліцейські використовують копінг-стратегію - вирішення проблем, що свідчить про високий рівень знань та навичок, стресостійкість, хорошу комунікацію 3 оточуючими, великий запас внутрішніх ресурсів, самоконтроль та адекватну самооцінку себе та своїх професійних дій.

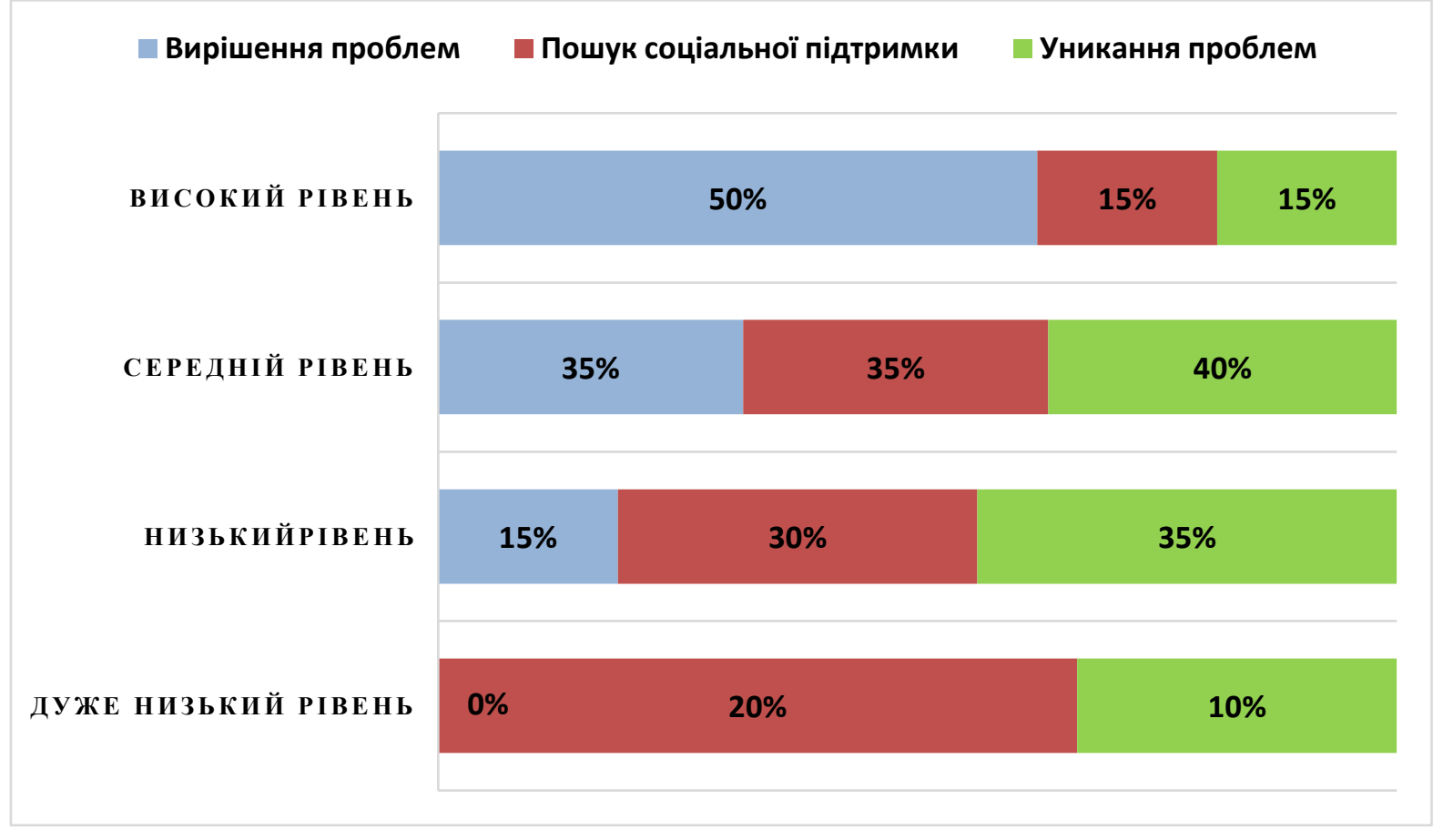

Puc. 3. Роподіл копінг-стратегій у респондентів

Із наведеної діаграми (рис. 4) видно, що у 50\% респондентів проявляється середній рівень прихованої емоційної напруженості, у 35\% респондентів низький рівень напруженості, та у 15\% - високий рівень. Отже, можна говорити, що в патрульних поліцейських домінує середній рівень накопичення емоційноенергетичних зарядів.

Наявність прихованої емоційної напруженості свідчить про те, що робота патрульних поліцейських супроводжується високою відповідальністю та точністю у виконанні власних дій. У їх роботі завжди присутній ризик, що впливає на емоційний стан, а це в свою чергу породжує стан напруженості. В силу умов та вимог праці патрульних поліцейських, їм не завжди вдається вчасно зняти стрес та емоційно розрядитись, тому у них і виникає стан прихованої емоційної напруженості. Наявність середнього рівня емоційної прихованої напруги у респондентів свідчить також про емоційне виснаження, що в подальшому може спричини емоційне та професійне вигорання. 


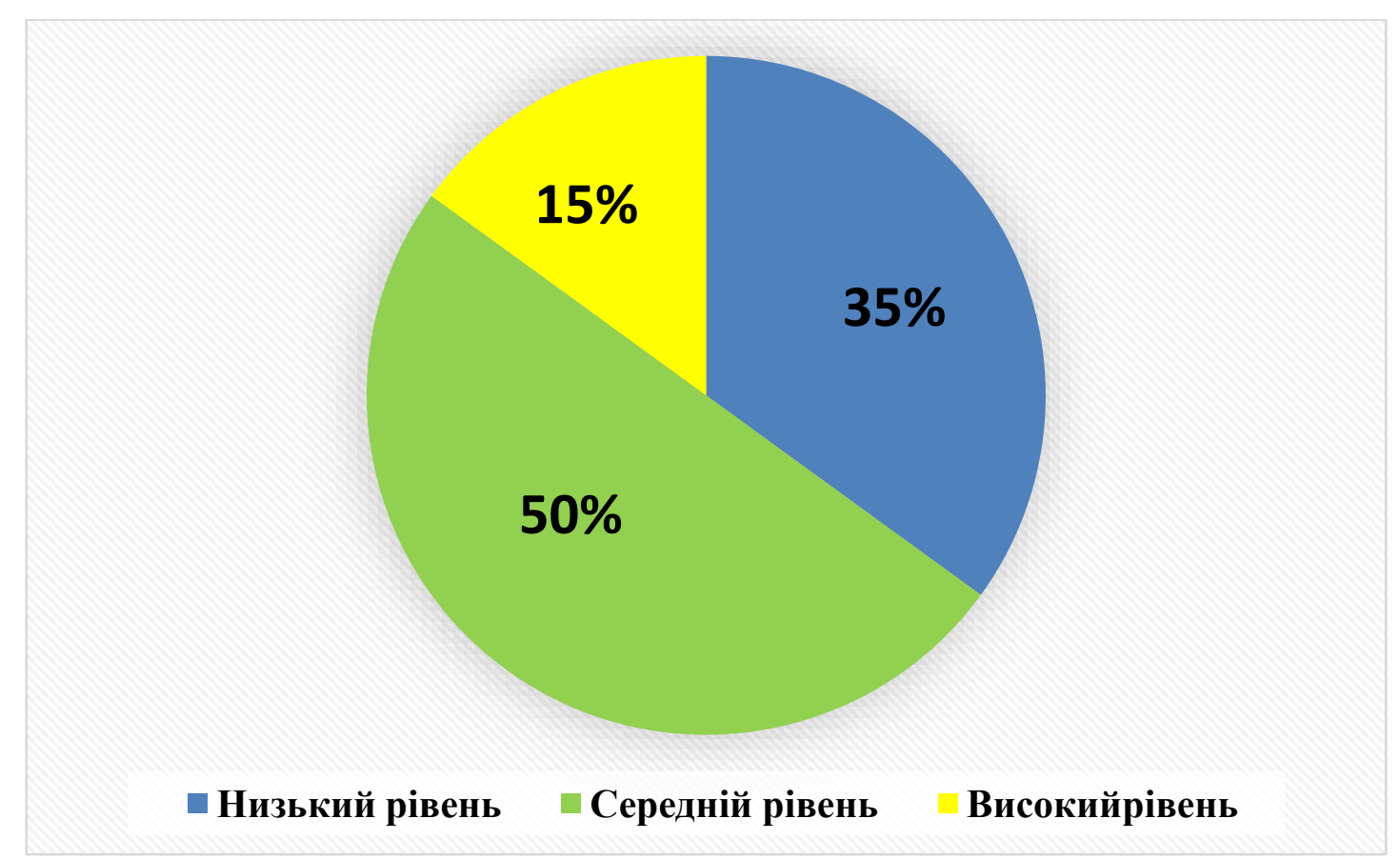

Pис. 4. Розподіл рівня прихованої емоційної напруженості респондентів

Отже, після аналізу отриманих емпіричних даних за усіма методиками, ми з'ясували, що психологічна підготовка патрульних поліцейських до діяльності в складних ситуаціях $є$ актуальною проблемою, оскільки даний вид діяльності вимагає від них стійкості нервових процесів, емоційної стабільності, конкретних поведінкових стратегій, мотивації до вирішення конфліктних ситуацій, стресостійкості та адаптивності.

Висновки. Підсумком теоретичного аналізу вищезазначеної проблеми психологічної підготовки $є$ формування стану професійно-психологічної готовності співробітника національної поліції як сукупності психофізіологічних, морально-психологічних, професійних і соціально-психологічних характеристик, властивостей і якостей, які відповідають особливостям оперативно-службової діяльності і виступають внутрішньою умовою іiі успішного здійснення. Психологічна підготовка патрульних поліцейських до діяльності в складних ситуаціях $є$ актуальною проблемою, оскільки даний вид діяльності вимагає від них стійкості нервових процесів, емоційної стабільності, конкретних поведінкових стратегій, мотивації до вирішення конфліктних ситуацій, стресостійкості та адаптивності. Емпіричне дослідження показало, що працівники патрульної поліції потребують допомоги стосовно покращення показників психологічної готовності до стресогенних ситуацій.

Таким чином, психологічна практика має грунтуватися на розробці й впровадженні психологічних засобів підготовки операторів патрульної 
поліції до діяльності в складних ситуаціях короновірусної пандемії, про що буде висвітлено у наступних публікаціях.

\section{Лimepamypa:}

1. Алещенко В. І., Сафін О. Д., Потапчук Є. М. Організація забезпечення збереження психічного здоров'я військовослужбовців. Київ, 2007. -134 с.

2. Бабаян Ю. О. Особливості психологічної готовності військовослужбовців до дій в екстремальних умовах. Збірник наукових праць Миколаївського національного університету імені В. О. Сухомлинського. Миколаїв: МНУ імені В. О. Сухомлинського, 2014. -С. 17-21.

3. Військова психологія та педагогіка: інноваційний підхід: підручник: у 2 ч. Ч. 1 / за заг. ред. С.Д. Максименка. Київ: НУОУ, 2012.- 472 с.

4. Осьодло В. І. Психологія професійного становлення офіцера: монографія. Київ: ПП «Золоті Ворота», 2012. -463 c.

5. Помиткіна Л.В., Помиткін Е.О. Психологія праці і відпочинку: підручник [для студ. вищ. навч. закл.] / Любов Віталіївна Помиткіна, Едуард Олександрович Помиткін. - К.: ТОВ «Альфа-ПІК», 2019. - 324 с.

6. Про Національну поліцію: закон України від 02.07.2015 № 580-VIII. Відомості Верховної Ради України. 2015. № 40-41. Ст. 379.

7. Психологія праці у звичайних та екстремальних умовах: навч. посіб. / М. С. Корольчук та ін. Київ: КНТЕУ, 2015. -652 с.

8. Смирнов Б. А., Долгополова Е. В. Психология деятельности в экстремальных ситуациях: 2-е изд., испр. и доп. Харьков: Гуманитарный центр, 2007. 292 с.

9. Фугелова Т.А. Инженерная психология. Учебник. - Тюмень: ТюмГНГУ, 2010. - 291с.

10. L. Pomytkina, A. Gudmanian, O. Kovtun, S. Yahodzinskyi, Personal choice: strategic life decision-making and conscience, E3S Web of Conferences, Vol.164, 10021 (2020) https://doi.org/10.1051/e3sconf/202016410021 Scopus

11. Pomytkina L.V., Polukhina M.P. Features of value-motivational sphere of law enforcers in the period of the crisis of professional formation. Socialization \& Human Development: International Scientific Journal. Volume 1. №1 / Kyiv Taras Shevchenko National University, University of Szczecin (Poland), Ukrainian Association of Educational and Developmental Psychology (Ukraine) Szczecin, Kyiv, 2019. - Pagess 50-57. https://doi.org/10.37096/SHDISJ-19-1.1

12. Pomytkin E. O., Pomytkina L. V. Strategy and Tactics of Conscious Psychological Counteraction of Humanity to Viral Diseases / Philosophy, psychology and pedagogics against COVID-19: Manual / Ed. : V.V. Rybalka, A.P. Samodryn, O.V. Voznyuk and others; a team of authors. Zhytomyr: Private enterprise Euro-Volyn, 2020. p.119-133.

http://emed.library.gov.ua/jspui/handle/123456789/160

13. Shevchuk D., Yakushenko O., Pomytkina L., Medynskyi and Shevchenko Y. Neural Network Model for Predicting the Perfomance of a Transport Task. Proceedings of the XIII International Scientific Conference on Architecture and Construction, 2020, LNCE 130, Springer, Singapore, pp. 271-278, 2021. Scopus

https://doi.org/10.1007/978-981-33-6208-6_27

https://static-content.springer.com/pdf/bok\%3A978-981-33-6208-6.pdf?token=1611403851339-793769a55b43cd628cc193df596a987a2af8bb2f09d0a7d7f8ece90ababd136c6566a23d443a2bcf68cfab 46162871dc4cafcd0bf7e7183dd8ad7cdadf33a2f3

14. Yakovytska, L., Pomytkina, L., Itchanska, O., Hirchuk, O., \& Veselska, O. (2019). Regression analysis of personality and social-psychological correlations of scientific and technical 
specialists responsibility. In CEUR Workshop Proceedings (Vol. 2588). CEUR-WS: 545-554. ISSN: 16130073 Scopus

https://www.scopus.com/record/display.uri?eid=2-s2.0-85083267525\&origin=resultslist\&sort= plf-f\&src=s\&sid=132c92b3be45aa16e 5c16bc03bd51851\&sot $=$ autdocs\&sdt=autdocs\&sl=18\&s=AUID\%2857193055459\%29\&relpos=2\&citeCnt=0\&searchTerm $=$

\section{References:}

1. Aleshhenko V. I., Safin O. D., Potapchuk C. M. Organizacija zabezpechennja zberezhennja psihichnogo zdorov'ja vijs'kovosluzhbovciv. Kiïv, 2007. -134 s.

2. Babajan Ju. O. Osoblivosti psihologichnoï gotovnosti vijs'kovosluzhbovciv do dij v ekstremal'nih umovah. Zbirnik naukovih prac' Mikolaïvs'kogo nacional'nogo universitetu imeni V. O. Suhomlins'kogo. Mikolaïv: MNU imeni V. O. Suhomlins'kogo, 2014. -S. 17-21.

3. Vijs'kova psihologija ta pedagogika: innovacijnij pidhid: pidruchnik: u $2 \mathrm{ch}$. Ch. 1 / za zag. red. S.D. Maksimenka. Kiïv: NUOU, 2012.- 472 s.

4. Os'odlo V. I. Psihologija profesijnogo stanovlennja oficera: monografija. Kiïv: PP «Zoloti Vorota», 2012. -463 s.

5. Pomitkina L.V., Pomitkin E.O. Psihologija praci i vidpochinku: pidruchnik [dlja stud. vishh. navch. zakl.] / Ljubov Vitaliïvna Pomitkina, Eduard Oleksandrovich Pomitkin. - K.: TOV «Al'fa-PIK», 2019. - 324 s.

6. Pro Nacional'nu policiju: zakon Ukraïni vid 02.07.2015 № 580-VIII. Vidomosti Verhovnoï Radi Ukraïni. 2015. № 40-41. St. 379.

7. Psihologija praci u zvichajnih ta ekstremal'nih umovah: navch. posib. / M. S. Korol'chuk ta in. Kiïv: KNTEU, 2015. -652 s.

8. Cmirnov B. A., Dolgopolova E. V. Psihologija dejatel'nosti v jekstremal'nyh situacijah: 2-e izd., ispr. i dop. Har'kov: Gumanitarnyj centr, 2007. 292 s.

9. Fugelova T.A. Inzhenernaja psihologija. Uchebnik. - Tjumen': TjumGNGU, 2010. - 291s.

10. L. Pomytkina, A. Gudmanian, O. Kovtun, S. Yahodzinskyi, Personal choice: strategic life decision-making and conscience, E3S Web of Conferences, Vol.164, 10021 (2020) https://doi.org/10.1051/e3sconf/202016410021 Scopus

11. Pomytkina L.V., Polukhina M.P. Features of value-motivational sphere of law enforcers in the period of the crisis of professional formation. Socialization \& Human Development: International Scientific Journal. Volume 1. №1 / Kyiv Taras Shevchenko National University, University of Szczecin (Poland), Ukrainian Association of Educational and Developmental Psychology (Ukraine) Szczecin, Kyiv, 2019. - Pagess 50-57. https://doi.org/10.37096/SHDISJ-19-1.1

12. Pomytkin E. O., Pomytkina L. V. Strategy and Tactics of Conscious Psychological Counteraction of Humanity to Viral Diseases / Philosophy, psychology and pedagogics against COVID-19: Manual / Ed. : V.V. Rybalka, A.P. Samodryn, O.V. Voznyuk and others; a team of authors. Zhytomyr: Private enterprise Euro-Volyn, 2020. p.119-133.

http://emed.library.gov.ua/jspui/handle/123456789/160

13. Shevchuk D., Yakushenko O., Pomytkina L., Medynskyi and Shevchenko Y. Neural Network Model for Predicting the Perfomance of a Transport Task. Proceedings of the XIII International Scientific Conference on Architecture and Construction, 2020, LNCE 130, Springer, Singapore, pp. 271-278, 2021. Scopus

https://doi.org/10.1007/978-981-33-6208-6_27 
https://static-content.springer.com/pdf/bok\%3A978-981-33-6208-6.pdf?token=1611403851339-793769a55b43cd628cc193df596a987a2af8bb2f09d0a7d7f8ece90ababd136c6566a23d443a2bcf68cfab 46162871dc4cafcd0bf7e7183dd8ad7cdadf33a2f3

14. Yakovytska, L., Pomytkina, L., Itchanska, O., Hirchuk, O., \& Veselska, O. (2019). Regression analysis of personality and social-psychological correlations of scientific and technical specialists responsibility. In CEUR Workshop Proceedings (Vol. 2588). CEUR-WS: 545-554. ISSN: 16130073 Scopus

https://www.scopus.com/record/display.uri?eid=2-s2.0-85083267525\&origin=resultslist\&sort= plf-f\&src=s\&sid=132c92b3be45aa16e 5c16bc03bd51851\&sot $=$ autdocs\&sdt=autdocs\&sl=18\&s=AUID\%2857193055459\%29\&relpos=2\&citeCnt=0\&searchTerm $=$ 